\title{
PENGEMBANGAN MODEL PEMBINAAN SD MUHAMMADIYAH DI MALANG RAYA UNTUK MENJADI SEKOLAH PPL BAGI MAHASISWA PGSD-UMM
}

\author{
Endang Poerwanti \\ e-mail : endangpoer@yahoo.com
}

\begin{abstract}
To be able to equip students to be professional teacher candidates required completion of curriculum, effective and giving lectures free experience teaching in elementary schools, so that takes SD Partners namely SD Muhammadiyah Malang. The purpose of research is the analysis of SD Partner readiness to be able to build a school PPL PGSD students. Planned two-year study, the findings of the first year of completion map SD SD Mitra to be training and training needs analysis I mentoring required. The second is the result of the completion of training programs and materials. First year potential mapping methodology SD Partners, using instruments effective schools and school inkator air MBS, and education Inclusion map gap between the ideal and the conditions and factual circumstances, be used as a material representation of FGD with KS and teachers to develop models appropriate training and mentoring leisure needs.
\end{abstract}

\begin{abstract}
Abstrak: Untuk dapat membekali mahasiswa menjadi calon guru profesional diperlukan penyiapan kurikulum, perkuliahan yang efektif dan pemberian pengalaman lapang mengajar di SD, sehingga diperlukan SD Mitra yaitu SD Muhammadiyah di kota Malang. Tujuan penelitian adalah analisis kesiapan SD Mitra untuk menjadi sekolah PPL yang dapat membina mahasiswa PGSD. Penelitian dirancang dua tahun, temuan tahun pertama adalah peta kesiapan SD Mitra untuk menjadi SD latihan dan analisis kebutuhan pelatihan / pendampingan yang diperlukan. Hasil tahun kedua adalah penyiapan program dan materi pelatihan. Metodologi tahun pertama pemetaan potensi SD Mitra, dengan menggunakan instrumen inkator sekolah efektif dan sekolah ber MBS, dan pendidikan Inklusi peta kesenjangan antara kondisi ideal dan dan kondisi faktual, akan digunakan sebagai materi FGD dengan KS dan perwakilan guru untuk mengembangkan model pelatihan dan pendampingan yang sesuai dengan kebutuhan lapang.
\end{abstract}

Kata Kunci: kesiapan SD mitra PGSD

Standar kompetensi guru kelas SD-MI Lulusan S1 PGSD yang ditetapkan Direktorat Ketenagaan, Ditjen DIKTI Standar Kompetensi Guru Kelas SD-MI Lulusan S1 PGSD yang ditetapkan oleh Direktorat Ketenagaan, Direktorat Jenderal Pendidikan Tinggi, Departemen Pendidikan Nasional Tahun 2006, yang disempurnakan dengan Peraturan Menteri DIKNAS Nomor 16 tahun 2007, ditetapkan berdasarkan tataran dan substansi kompetensi.

Berdasar standar tersebut PGSD Universitas Muhammadiyah Malang menjabarkan kurikulum yang secara substantif dikelompokkan ke dalam lima rumpun kompe- tensi (core-competencies), yaitu (1) penguatan wawasan tentang pendidik yang berbudi luhur, (2) pengenalan peserta didik secara mendalam, (3) penguasaan bidang studi, (4) penyelenggaraan pembelajaran yang mendidik, dan (5) pengembangan kemampuan profesional secara berkelanjutan. Untuk menyiapkan lulusan tersebut diperlukan penyiapan kurikulum dan perangkatnya, perkuliahan yang efektif dan pemberian pengalaman lapang mengajar di SD. Berbagai keahlian yang dipersyaratkan untuk menjadi calon guru profesional, tidak semuanya dapat disiapkan di kampus, tetapi harus juga diberikan bekal pengalaman lapang khusus- 
nya yang terkait dengan dunia ke-SD-an.

Aspek penelitian meliputi kesiapan SD muhammadiyah kota Malang dalam sumber daya manusia, manajemen, fasilitas, kurikulum dan perangkatnya, model pembelajaran dan peran serta masyarakat sebagai gambaran dari sekolah efektif dan memiliki wawasan peningkatan mutu berbasis sekolah (PMBS), untuk siap menerima dan membina dan memberi pengalaman lapang bagi mahasiswa PGSD menjadi lulusan yang siap mengajar lima bidang studi dan bersaing di dunia kerja.

Kemitraan antara SD latihan dengan Prodi S-1 PGSD untuk berbagai kegiatan peningkatan kapasitas perlu terus dilakukan, untuk mencapai kemitraan yang efektif. Hal yang perlu diperhatikan dalam mengembangkan S1-PGSD yang berkualitas adalah perlunya mencermati konteks pendidikan di SD. Berbagai permasalahan yang ditemui dalam konteks SD perlu diantisipasi dengan cara mengembangkan program S1-PGSD yang responsif dan sesuai dengan konteks SD. Berbagai upaya penyiapan program S1-PGSD dan pemahaman konteks SD diharapkan dapat memberikan kesempatan kepada mahasiswa untuk mendapatkan layanan perkuliahan yang berkualitas sesuai dengan tuntutan PP 19 tahun 2005.

Salah satu upaya pengembangan program studi S1-PGSD Universitas Muhammadiyah Malang adalah pemahaman bagaimana konteks pendidikan dasar di SD Muhammadiyah di kota Malang sebagai tempat Praktek Pengalaman Lapang (PPL) bagi mahasiswa. Sehingga permasalahan yang ingin dipecahkan adalah: "Bagaimanakah potensi dan kelemahan dari SD tempat mahasiswa PPL, untuk menyusun program pengembangan kapasitas dan manajemen sekolah, sekaligus bekal bagi mahasiswa yang akan PPL".

Sesuai dengan latar belakang masalah dan permasalahan utama penelitian yaitu "Bagaimanakah potensi dan kelemahan dari SD tempat mahasiswa PPL, untuk me- nyusun program pengembangan kapasitas dan manajemen sekolah, sekaligus bekal bagi mahasiswa yang akan PPL". Permasalahan tersebut terjabar dalam beberapa masalah penelitian yang dirumuskan sebagai berikut (1) bagaimanakah ciri-ciri/karakteristik sekolah efektif dan pilar-pilar manajemen berbasis sekolah yang menjadi kriteria sekolah siap sebagai tempat PPL?, (2) bagaimanakah kualitas manajemen sekolah di SD Muhammadiyah kota Malang?, (3) bagaimanakah peran serta masyarakat-stakeholder yang mampu mendukung penciptaan sekolah dan pembelajaran yang efektif di SD Muhammadiyah kota Malang?, (4) bagaimanakah peta kesenjangan antara kondisi ideal SD PPL dengan kondisi faktual yang ada di SD Muhammadiyah kota Malang?, dan (5) kebutuhan dan model pendampingan bagaimana yang diperlukan untuk meningkatkan kesiapan SD Muhammadiyah menjadi sekolah PPL.

Sejalan dengan masalah penelitian yang dirumuskan, maka temuan yang ditargetkan pada tahun pertama (2011-2012) adalah peta kemampuan dan kesiapan SD Muhammadiyah untuk menjadi SD latihan berbasis pendidikan Inklusi (PPL) bagi mahasiswa PGSD UMM, dan analisis kebutuhan dan model pendampingan yang diperlukan untuk meningkatkan kesiapan SD Muhammadiyah menjadi sekolah PPL. Hasil penelitian yang ditargetkan tersebut dapat dijabarkan menjadi beberapa tujuan penelitian yaitu :

1. Mendekripsikan ciri-ciri/karakteristik sekolah efektif dan pilar-pilar manajemen berbasis sekolah yang menjadi kriteria sekolah yang siap menerima mahasiswa PGSD melaksanakan PPL.

2. Mendekripsikan kualitas manajemen peningkatan mutu berbasis sekolah yang ada di SD Muhammadiyah kota dan kabupaten Malang.

3. Mendekripsikan peran serta masyarakat/ stake-holder yang mampu mendukung penciptaan sekolah dan pembelajaran ya- 
yang efektif di SD Muhammadiyah kota dan kabupaten Malang.

4. Mendekripsikan peta kesenjangan antara kondisi ideal SD PPL dengan kondisi faktual yang ada di SD Muhammadiyah kota dan kabupaten Malang.

5. Mendekripsikan kebutuhan dan model pendampingan yang diperlukan untuk meningkatkan kesiapan SD Muhammadiyah menjadi sekolah PPL.

\section{METODE PENELITIAN}

Penelitian ini pada dasarnya merupakan penelitian eksploratif yang berupaya untuk mencari data-data empiris dan menyusun analitis kritis dalam memetakan kompetensi apa yang sebenarnya dibutuhkan guru dalam mengelola pembelajaran di sekolah inklusi, tanpa melakukan intervensi dan hipotesis. Metode penelitian paradigma kualitatif yang dilengkapi dengan data kuantitatif untuk memperjelas paparan kualitatif. Penentuan lokasi ditentukan secara purposive atau dipilih dengan sengaja karena karakteristik wilayah yang dipilih sesuai dengan tujuan penelitian yaitu Kota dan kabupaten Malang. Penetapan sekolah yakni di semua SD Muhammadiyah di kota dan kabupaten Malang sebagai lokasi penelitian juga dipilih secara purposive dengan pertimbangan bahwa secara struktural berada dibawah amal usaha Muhammadiyah yang memerlukan pembinaan dan pendampingan dari perguruan tinggi Muhammadiyah sebagai pembina, agar dapat memenuhi tuntutan sebagai Sekolah berkualitas, disamping kekepentingan penyiapan sebagai sekolah PPL. Dalam penelitian ini ditetapkan 8 SD Muhammadiyah yaitu semua SD Muhammadiyah yang ada di kota Malang berjumlah 7 SD, dan 1 SD di kabupaten Malang yang memang di- gunakan untuk praktek pengalaman lapang oleh mahasiswa PGSD.

Responden penelitian juga ditetapkan secara purposif, dalam penelitian ini responden terdiri dari dua kelompok yaitu dalam langkah awal untuk menyusun instrumen (panduan wawancara dan panduan observasi), informan yang dilibatkan dalam FGD adalah Tim dosen PGSD dan kepala sekolah. Semua guru dan komite pada SD sampel yang menjadi sasaran penelitian.

Untuk mencapai tujuan di atas kegiatan yang dilakukan adalah (1) penyusunan instrumen potensi sekolah dengan menggunakan acuan pilar-pilar sekolah efektif dan sekolah ber MBS, sebagai kriteria sekolah latihan (PPL) berbasis pendidikan inklusi, (2) pelaksanaan pengumpulan data Potensi Sekolah, dengan menggunakan instrumen yang telah disiapkan, dan (3) Need Assesment, untuk menyusun peta pengembangan yang dibutuhkan oleh SD latihan untuk mencapai sekolah efektif atau sekolah berMBS berbasis pendidikan inklusi.

Secara garis besar metode pengumpulan data dalam penelitian ini menggunakan 4 (empat) metode yang digunakan secara simultan dan saling melengkapi, karena pada dasarnya masing-masing metode lebih cocok untuk mengumpulkan data tentang variabel tertentu dan akan saling melengkapi penggunaan metode pengumpulan data yang lain. Empat metode pengumpulan data tersebut adalah :

Focus Group Discussion (FGD): adalah penggunaan forum diskusi dalam kelompok yang anggotanya dibatasi kriteria tertentu dengan pembahasan yang dibatasi atau terfokus pada topik tertentu tanpa perlu kesepakatan bulat atau kesimpulan yang merupakan keputusan bersama. Angket digunakan untuk mengetahui kesiapan SD Muhammadiyah menjadi sekolah PPL, yaitu sekolah efektis dan ber MBS berbasis pendidikan inklusi. Wawancara yang digunakan adalah Indept Interview (wawancara mendalam) sesuai dengan permasalahan yang diungkap maka pengumpulan data akan bersifat konteks terfokus, dengan peneliti sebagai instrumen utama dibantu panduan wawancara akan dilakukan pada kepala sekolah dan guru pada tiap sekolah untuk 
melengkapi data angket. Wawancara dilakukan secara individual maupun diskusi bersama dengan guru, KS, komite dan perwakilan yayasan untuk mendapat data tentang pengetahuan, keterampilan dan pendampingan yang dibutuhkan guru dan sekolah. Hasilnya akan digunakan sebagai langkah awal penyusunan program pendampingan pada program tahun kedua. Observasi digunakan dalam mengidentifikasi permasalahan yang terkait dengan lingkungan sekolah. Termasuk untuk melihat dokumentasi administrasi sekolah, dan informasi lain yang dianggap perlu untuk melengkapi data yang terkumpul dengan angket, wawancara maupun observasi.

Karena data berhubungan dengan paparan perilaku dan pernyataan serta persepsi maka data yang pada umumnya berupa data kualitatif, sedang beberapa data yang berupa angka atau kuantitatif akan digunakan untuk melengkapi dan membantu pendiskripsian data kualitatif. Analisis yang digunakan berupa sajian secara kuantitatif untuk data-data yang dapat diangkakan, baik berupa prosentase, tabulasi frekuensi ataupun kross tabulasi, sedang data yang bersifat kualitatif yang tidak dapat disajikan secara klasifikatoris, akan disajikan dan dianalisis secara kualitatif sesuai dengan komponen permasalahan dan tujuan penelitian.

Analisis kualitatif yang dipilih adalah analisis fenomenologis dan pola kecenderungan dilakukan sepanjang waktu penelitian.

Penelitian ini dirancang dalam dua tahun, tahun pertama adalah peta kemampuan dan kesiapan SD Muhammadiyah untuk menjadi SD latihan berbasis pendidikan Inklusi (PPL) bagi mahasiswa PGSD UMM, dan analisis kebutuhan dan model pendampingan yang diperlukan untuk meningkatkan kesiapan SD Muhammadiyah menjadi sekolah PPL. Sedang tahun kedua adalah penyiapan dan pengembangan materi untuk meningkatkan SDM dan manajemen yang ada di sekolah PPL. Hasil Penelitian tahun pertama adalah (1) instrumen yang berupa kondisi ideal sekolah Latihan yaitu sekolah efektif yang ber MBS, (2) peta potensi sekaligus peta kesenjangan SD Muhammadiyah di kota Malang untuk menjadi sekolah PPL, (3) peta kesiapan SD Muhammadiyah di kota Malang untuk menjadi sekolah PPL berbasis pendidikan inklusi (4) model pembinaan, pelatihan dan pendampingan yang dibutuhkan masing-masing SD Muhammadiyah untuk menjadi sekolah PPL berbasis pendidikan inklusi.

\section{HASIL PENELITIAN DAN PEMBAHASAN}

Kondisi masing-masing sekolah $\mathrm{Mu}-$ hammadiyah di kota dan kabupaten Malang pada saat ini masih beragam. Ada satu sekolah yang kondisinya sudah sangat mapan, baik dari kondisi sekolah, jumlah siswa, jumlah guru profesionalnya, serta proses belajar dan pembelajarannya. Sebaliknya ada sekolah yang masih sangat memerlukan pembinaan atau kerjasama dari pihak universitas dalam hal ini program studi PGSD dalam mendukung perkembangannya. Untuk itu diperlukan rumusan keterampilan dan pengetahuan tentang pilar-pilar manajemen berbasis sekolah. Dari hasil obervasi yang telah dilaksanakan ke 8 (delapan) Sekolah Dasar Muhammadiyah di kota dan kabupaten Malang, maka hasil yang telah didapatkan harus dianalisis untuk menentukan kondisi sekolah serta kesenjangan yang terjadi diantara sekolah-sekolah tersebut. Hasilnya adalah sebagai berikut.

\section{Kejelasan Visi dan Misi Sekolah}

Visi dan misi sekolah dikembangkan menjadi 5 deskriptor/terdiri dari 5 item, dengan skor maksimal pada sub bagian ini adalah 15. Hasil yang dicapai pada setiap sekolah menunjukkan hasil yang cukup baik dengan kisaran skor antara $12-15$. Hal ini menunjukkan bahwa sebagian besar SD 
Muhammadiyah telah memiliki Visi dan Misi Sekolah yang jelas. Hasil secara rinci adalah tiga sekolah yang mendapat nilai sempurna, Skor 14 ada dua SD sedang dua SD yang lain skor nya 13 . Skor rata-rata untuk semua sekolah pada aspek ini adalah 2.775. Sehingga secara umum aspek kejelasan visi dan misi sekolah ini cukup memuaskan pada semua SD Muhammadiyah.

\section{Profesionalisme Kepala Sekolah}

Aspek profesionalisme Kepala Sekolah menjadi faktor penting dalam pengembangan sekolah efektif, aspek ini dijabarkan dalam 11 deskriptor/item, sehingga skor maksimal pada aspek ini adalah 33. Hasil lapang menunjukkan dua sekolah memperoleh skor maksimal 33, dua sekolah dengan skor 32, Skor yang paling rendah (22), namun secara keseluruhan penilaian terhadap profesionalisme kepala Sekolah SD Muhammadiyah cukup baik. Skor rata-rata untuk semua sekolah pada aspek profesionalisme kepala sekolah adalah 2.72. Sehingga secara umum aspek profesionalisme kepala sekolah ini cukup memuaskan pada semua SD Muhammadiyah.

\section{Profesionalisme Guru}

Guru yang profesional menjadi ujung tombak keberhasilan pembelajaran yang pada ujungnya mendukung peningkatan kualitas lulusan dan prestasi sekolah. Profesionalisme guru dijabarkan dalam 9 deskriptor/9 item dengan skor ideal adalah 27. Hasil di lapangan menunjukkan bahwa pada aspek ini belum ada sekolah yang mencapai skor ideal, skor tertinggi adalah 26, sedang SD yang lain memerlukan peningkatan profesionalisme guru karena skornya masih di bawah 20. Dari data tersebut menunjukkan bahwa profesionalisme guru di SD Muhammadiyah masih perlu banyak pendampingan.

\section{Lingkungan yang Kondusif}

Lingkungan yang kondusif adalah faktor pendukung yang pelu mendapat perhatian pada sekolah efektif. Aspek ini dijabarkan dalam 6 item dengan skor maksimal 18. Hasil di lapangan menunjukkan bahwa skor pada aspek ini sudah sangat baik empat SD mencapai skor maksimal yaitu, sesedang yang lain masih memerlukan pembinaan dalam pengembangan lingkungan sekolah yang kondusif, karena skor yang diperoleh masih paka rentang 10-12. Skor rata-rata untuk semua sekolah pada aspek lingkungan sekolah adalah 2.58. Sehingga secara umum aspek lingkungan sekolah ini masih berada pada klasifikasi cukup meskipun beberapa SD sudah pada klasifikasi memuaskan.

\section{Ramah Siswa}

Lingkungan yang kondusif ada sub aspek yang secara spesifik mensyaratkan adanya lingkungan yang ramah siswa, (3 item) skor Maksimal untuk aspek ini adalah 9. Data lapang menunjukkan bahwa satu SD telah mencapai skor maksimal, enam SD mencapai skor baik dengan skor antara 6-8, hanya satu SD baru mencapai skor 3. Skor rata-rata untuk semua sekolah pada aspek lingkungan sekolah yang ramah siswa adalah 2.25. Sehingga secara umum aspek ini masih kurang dan perlu pendampingan untuk mencapai kondisi ideal.

\section{Manajemen Sekolah yang Kuat}

Manajemen sekolah menyangkut kepemimpinan, pengembangan, perencanaan sistem promosi, susana kerja, kepatuhan terhadap peraturan perundangan dan kepuasan warga sekolah. Berbagai sub aspek tersebut terjabar dalam 15 dekriptor, sehingga skor maksimal untuk aspek ini adalah 45. Data lapang menunjukkan bahwa secara umum skor untuk aspek ini masih kurang, 
karena rata rata untuk semua sekolah baru mencapai skor 2.26, bahkan ada sekolah yang kurang dari 1.5, meskipun ada pula sekolah yang sudah berada pada skor di atas 2.75 dari 2.5. namun secara keseluruhan aspek ini masih sangat perlu untuk dikembangkan.

\section{Kurikulum yang Luas dan Berimbang}

Kurikulum yang luas dan berimbang pada suatu sekolah akan sangat menentukan keberhasilan siswa dalam mencapai Standar kompetensi lulusan. Kurikulum yang luas dan berimbang dijabarkan dalam 5 deskriptor, sehingga skor maksimal untuk aspek kurikulum yang luas dan berimbang ini adalah 15. Data di lapangan menunjukkan bahwa skor rata rata pada semua sekolah masih sangat jauh dari memuaskan, karena hany mencapai 2.12. bahkan ada sekolah yang skornya hanya 1. Aspek kurikulum juga merupakan skor terrendah dari 9 aspek yang ditetapkan sebagai indikator sekolah efektif.

\section{Penilaian dan Pelaporan Hasil Belajar Siswa}

Penilaian dan pelaporan prestasi siswa yang bermakna terjabar dalam 5 deskriptor/5 item dengan skor maksimal 15 . Hasil di lapangan menunjukkan bahwa skor pada aspek ini sudah sangat baik satu SD mencapai skor maksimal tiga SD mendapat skor 14 sedang yang lain masih memerlukan pembinaan. Rata rata skor untuk semua sekolah adalah 2.475. Sehingga secara umum aspek lingkungan sekolah ini masih berada pada klasifikasi cukup meskipun beberapa SD sudah pada klasifikasi memuaskan.

\section{Pelibatan Masyarakat}

Aspek pelibatan masyarakat ini terdiri dari 9 item, sehingga skor maksimal untuk aspek ini adalah 27. Hasil di lapangan me- nunjukkan bahwa skor rata rata pada semua sekolah masih sangat jauh dari memuaskan, karena hanya mencapai 2.18 . bahkan ada sekolah yang skornya hanya 1,5 , meskipun ada 3 sekolah yang sudah mencapai skor 25. Aspek kurikulum juga merupakan skor terendah kedua dari 9 aspek yang ditetapkan sebagai indikator sekolah efektif atau sekolah yang berwawasan manajemen peningkatan muru berbasis sekolah.

\section{KESIMPULAN DAN SARAN}

\section{Kesimpulan}

Hasil penelitian secara keseluruhan dapat disimpulkan sebagai berikut

1. Ciri-ciri/karakteristik sekolah efektif dan pilar-pilar manajemen berbasis sekolah yang menjadi kriteria sekolah siap sebagai tempat PPL dijabarkan dalam sembilan aspek yang meliputi (1) kejelasan visi dan misi sekolah, (2) Profesionalisme Kelapa Sekolah, (3) Profesionalisme guru, (4) Lingkungan yang kondusif (5) Lingkungan yang ramah siswa, (6) Manajemen sekolah yang kuat, (7) Kurikulum yang luas dan berimbang (8) Penilaian dan pelaporan prestasi siswa bermakna, dan (9) Pelibatan masyarakat.

2. Hasil pemetaan menunjukkan bahwa skor tertinggi dari 9 aspek sekolah efektif adalah kejelasan visi dan misi sekolah, sedang yang terendah adalah aspek kurikulum dan keterlibatan masyarakat. Sedang skor keseluruhan pada setiap sekolah dapat dilaporkan urutan perolehan skor total adalah dua SD mencapai kualifikasi sangat baik, empat SD masuk pada kriteria baik dan dua SD yang lain papada kualifikasi cukup/sedang.

3. Terkait dengan kesiapan SD Muhammadiyah untuk menerima PPL yang berbasis pendidikan inklusi. Sebagian besar SD Muhammadiyah belum siap, baik dilihat dari hasil observasi, kesiapan sumber daya manusia maupun kesiapan sara- 
na dan prasarana. Sehingga untuk menyiapkannya diperlukan pelatihan, pendampingan dan bantuan teknis dari UMM. Hanya dua SD yang bisa dikatakan mulai membuka wawasan tentang pendidikan inklusi, dan berbenah dalam menyiapkan SDM maupun fasilitas sekolah.

4. Pelatihan dan pendampingan yang didiperlukan terutama adalah penyiapan SDM guru untuk meningkatkan wawasan tentang pendidikan inklusi, pelatihan 9 aspek sekolah efektif pada SD tertentu, khusus untuk peningkatan pelibatan masyarakat, dan bagaimana pengembangan kurikulum yang luas dan seimbang diperlukan untuk semua SD Muhammadiyah.

\section{Saran}

Saran yang dapat dikemukakan terkait dengan hasil yang telah dicapai adalah SD Muhammadiyah sebagai mitra PGSD tempat PPL harus selalu mendapat pendampingan untuk selalu melakukan pembaharuan dan siap menerima mahasiswa PPL, khususnya yang terkait dengan untuk meningkatakan wawasan tentang pendidikan inklusi, pelatihan 9 aspek sekolah efektif pada SD tertentu, khusus untuk peningkatan pelibatan masyarakat, dan bagaimana pengembangan kurikulum yang luas dan seimbang diperlukan untuk semua SD Muhammadiyah.

\section{DAFTAR PUSTAKA}

Abu-Duhou, I. 1999. Scholl-Based Management. United Nation Education Scientific and Cultural Organization, Paris: UNESCO.

Departemen Pendidikan Nasional. 2002. Manajemen Peningkatan Mutu Berbasis Sekolah (MPMBS). Jakarta.

Departemen Pendidikan Nasional. 2005. Peraturan Pemerintah No. 19 Tahun 2005 tentang Standar Nasional Pendidikan. Jakarta.

Fattah, Nanang. 2004. Konsep Manajemen Berbasis Sekolah (MBS) dan Dewan Sekolah. Bandung: Pustaka Bani Quraisy.

Gamage, D. 2003. School-Based Management Leads Shared Responsibility and Qualty in Education. EDRS: New Orleans, LA. 